\title{
E-Government: Challenges for Acceptance and Adoption in State of Punjab
}

\author{
Manjot Kaur \\ Assistant Professor \\ P.G. Department of Computer Science \\ G.S.S.D.G.S. Khalsa College, Patiala
}

\author{
Amitoj Singh, Ph.D. \\ Assistant Director- Research \\ Dept. of Computer Science Engineering \\ Chitkara University, Punjab
}

\begin{abstract}
E-government is basically an application of ICT to provide government services to the citizens by means of internet. This paper gives an overview of state of Punjab which includes economy overview, status of ICT and e-government in the state. In state of Punjab, where IT literacy rate is very low and large segment of population is living below the poverty line, also there is unawareness among the people regarding the usage and benefits of e-governments services. Hence, there exist a number of barriers to execute e-government service. This research paper discloses the major challenges for the acceptance and adoption of e-government services in state of Punjab.
\end{abstract}

\section{Keywords-}

E-government, e-readiness, literacy level, per capita income.

\section{PUNJAB: A GENERAL OVERVIEW}

\subsection{Background}

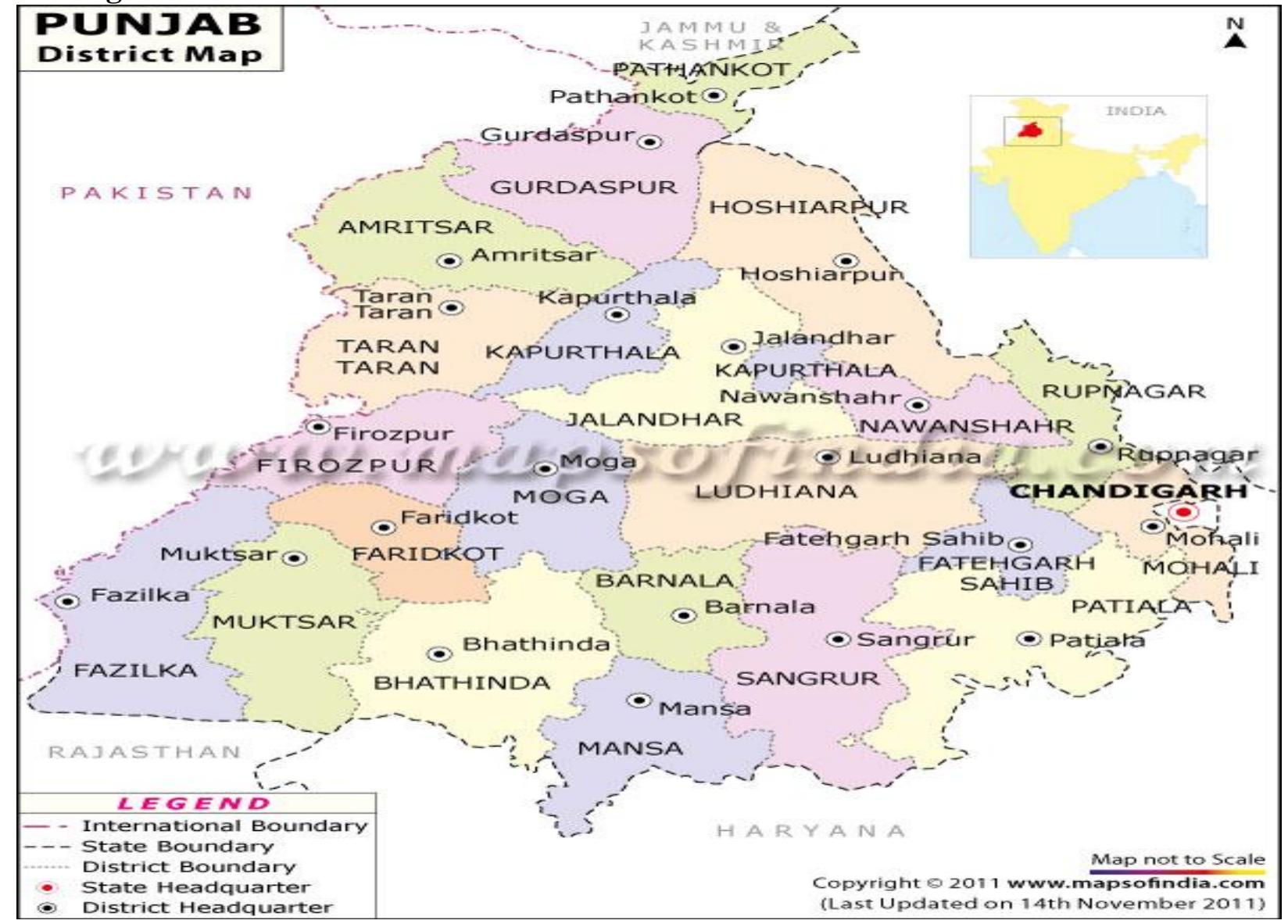

(Government of Punjab Annual Plan 2013-14, 2013)
The word Punjab is made up of two words "Panj" and "Aab" where Panj means five and Aab means water. This name was given to this region to signify its five rivers. Punjab is situated in north-west of India, bordered by Pakistan on the west, the Indian state of Jammu \& Kashmir on the north, Himachal Pradesh on its north-east and Haryana \& Rajasthan on its south having area of 50,362 sq. k.m. i.e. it covers $1.54 \%$ of the country's total geographical area (Geaographical Overview of Punjab, 2012). Punjab is known as the richest state of India that vibrates with the enthusiastic culture and always moved on the path of prosperity. As Punjab has been awarded National Productivity Award for agriculture extension services for successively 10 years from 1991-92 to 1998-99 and 2001 to 2003-04 So, Punjab is also known as "Food Basket and Granary of India" (Punjab:An Overview). It is first state in India to set up a technical university. Punjab has also won the Agriculture policy Leadership Award, 2013 (Progressive Punjab, 2013). 


\subsection{Economy-Overview}

The state's major economic resources are its fertile land, the irrigation systems and its well educated technically sound people. These aspects have contributed to achieve higher levels of productivity and a better competitiveness level in the global economy (The Booming Economy of Punjab, 2013). The leading ingredient of the Punjab economy is the agricultural sector. The state is prominent for its immense production of wheat. The industries based on agriculture are food products, beverages, cotton, wood as well as papers. The next branch of Punjab's economy is the livestock. In this particular field, it is one of the largest producers in India. The third stream is wildlife and forestry. It magnetizes the tourists and by that enhances the economy of Punjab (Economy of Punjab, 2013).

\subsection{ICT in Punjab}

E-governance involves ICTs, especially the internet to enhance the delivery of government services to citizens, businesses \& government agencies as well. Besides the public sector, it also includes the management and administration of policies and procedures in private sectors. Except the delivery of faster services, internet also provides more transparency between the government and the citizens (Mittal \& Kaur, March 2013). The literacy rank of Punjab is 21 (Indian states ranking by literacy rate, 2011). Therefore, having such low level of literacy, it is very much difficult for the government to provide its services to such citizens via the means of Internet. The E-readiness is defined as the ability to use information and communication technologies to develop one's economy and welfare. According to the Global Information Technology Report 2012, the e-readiness rank of India is 69 with the score of 3.89 out of 10 . Hence, the use of ICT in India is very low, likewise in Punjab as well. (Mittal \& Kaur, March 2013)

\subsection{E-Government in Punjab}

The e-government projects are implemented by government of India in a very efficient manner. As per the e-readiness reports of DIT (Department of Information Technology) of India, Andhra Pradesh, Punjab, Delhi, and Chandigarh \& Tamil Nadu are positioned as the leaders in the use of ICTs. Therefore, it can be said that, Punjab is one of the dominant state of India in ICT advancement. DoIT has been established in the state of Punjab. DoIT takes initiatives for the successful implementation of e-government projects in the state. The projects initiated by the state government \& DoIT are SUWIDHA, CSCs, e-Districts, VAHAN, SAARTHI (Mittal \& Kaur, E-Governance initiatives in the State of Punjab, 2013). E-government is one of the best ways to solve the social and economical problems that exists in state of Punjab. According to Deepak Ghaisas, former Chairman NASSCOM product forum and CEO India operations estimate " 23 percent of government spending goes on defense and 46 percent on governance. It will actually boost the domestic tech industry, if a small fragment is spent on technology to streamline the process. (Dwivedi \& Bharti)

\section{E-GOVERNMENT AND ITS ACCEPTANCE}

E-Government is a multidisciplinary term for web based services from agencies of local, state and federal governments. (Palvia \& Sharma, 2007) E-Government is the use of Information and Communication technologies, predominantly the Internet and World Wide Web, to enhance the efficiency, cost and quality of government information and services provided to its stakeholders such as citizens, businesses, employees and other government agencies. Although the adoption of e-government has the capability to accommodate better services to citizens at lower costs, it has acceptance problems. One of the most challenging issues in IT research is to understand why people accept or reject new information technology. (Adawi-AI, Yousafza, \& Pallister, September,2005)

World Bank (www.worldbank.org) definition: "EGovernment refers to the use by government agencies of information technologies such as Wide Area Network, the Internet and Mobile Computing that have the ability to transform relations with citizens, businesses and other arms of government. These technologies can serve a variety of different ends: better delivery of government services to citizens, improved interactions with business and industry, citizen empowerment through access to information or more efficient government management. The resulting benefits can be less corruption, increased transparency, greater convenience, revenue growth and /or cost reduction." (Palvia \& Sharma, 2007)

The acceptance and success of e-government largely depends upon citizen willingness to adopt this innovation. (Carter, 2005) Still, many governments face the problem of low level of citizen adoption of e-government services. (Belanger, 2008)The Adoption of E-government takes place in a violent social political climate. Therefore, it must be carefully outlines not only from technological perspectives, but also from social, political and cultural perspectives. Governments will not be able to take strategic actions to upgrade the egovernment without understanding what motivates the public to use e-government services. (Gilber, 2004)

\section{CHALLENGES FOR E- GOVERNMENT IN PUNJAB}

There are numerous hurdles in the execution of e-government in Punjab. These can be classified as follows-

\subsection{Low Literacy Level}

Literacy means the capacity to read and write with understanding in any language. A person who can just read but cannot write cannot be rated as literate. The literacy rate of Punjab is very low, which is acting as a major challenge for e-government adoption by the people.

\subsection{Low IT Literacy}

Majority of the people of Punjab are not literate and those who are literate, they do not have proper knowledge about the usage of Information Technology. So, in Punjab, such a low level of Information Technology is a major hurdle for egovernment adoption and acceptance by the people. To overcome this hurdle, people of Punjab must be made aware about the usage and benefits of Information Technology. (Malik, Priyanka, \& Verma, July 2014)

\subsection{Absence of Native Language}

The e-government applications are written in English language. This is one of the major reasons for the least acceptance and adoption of e-government as the acceptance and use of English language in Punjab is very low. Therefore, the e-government applications must be written in native language so that public may accept and adopt these applications very easily. (Malik, Priyanka, \& Verma, July 2014) 


\subsection{Lack of User Friendly Websites}

Majority of the users of e-government websites are non experts. Such users do need proper instructions to access the applications in an appropriate way. If the government websites will not be user friendly then, people cannot accept e-government services at large scale. Therefore, government websites must be user friendly so that more and more people can use them easily and utilize the facilities offered by the government. This challenge can be overcome by designing government websites in an easier format and by creating user friendly interface. (Mittal \& Kaur, March 2013)

\subsection{Privacy and Security}

Privacy and security of an individual's personal data that user provides to acquire government services is one of the crucial barrier in the acceptance of e-government services. Majority of the people do not accept and adopt e-government services because of the fear that the information which they are going to share such as income, contact numbers, medical history, bank details etc can be misused. Inadequacy of security measures can restrict the development as well as adoption of e-government services. (Mittal \& Kaur, March 2013)

\subsection{Identification of Applications}

The next major challenge for e-government adoption is identification of e-government facilities by the citizens. It is a big challenge to have all the citizens well aware of the facilities offered by the e-government and have them to trust in it, so that citizens may accept and adopt these facilities in an easy and efficient manner. (Mittal \& Kaur, March 2013)

\subsection{Less Awareness}

Most of the people of Punjab are not aware of the advantages of e-government services. Government also does not pay much attention to make the people conscious about egovernment applications. Due to unawareness about the egovernment services, people cannot accept and adopt the technology. (Malik, Priyanka, \& Verma, July 2014)

\subsection{Non-Integration of Services}

E-government services provided by state and central government are not integrated properly. The information that lies in one department has no meaning to other department, thus, it creates the lack of communication and sometimes miscommunications as well. Therefore, because of non integration of services, people hesitate to adopt the egovernment services, as the lack of communication between departments result in public's harassment. (Kumar \& Bhanti, September 2012)

\subsection{Inequality}

In Punjab, there exist an inequality between the individuals, communities and businesses that have access to Information Technology and those that do not have such access. Economic poverty is closely related to the limited IT resources. A large segment of population is living below the poverty line that is why they cannot afford computers and internet connections to access the e-government services. On the contrary, the economically well stable people do not have adequate knowledge about the usage and benefits of e-government services. Therefore, this difference acts as a major challenge in the acceptance and adoption of e-government services. (Dwivedi \& Bharti)

\subsection{Low per Capita Income}

Per capita income means how much each individual receives in terms of money, of the yearly income generated in a country or state. In other words, it refers to what each individual receives if the yearly national income is divided equally between everyone. As compare to other states, per capita income of Punjab is low. That is major cause of non adoption and least acceptance of online services by the people of Punjab. (Mittal \& Kaur, March 2013)

\section{CONCLUSION}

Punjab Government is taking many initiatives to offer egovernance services to the citizens. However, Government of Punjab has invested lot of money on e-government projects, but still these projects are not executing affluently. Inequality and unawareness in people, absence of native language, lack of security and privacy measures, less user friendly websites etc are the crucial challenges and factors that affect the acceptance and adoption of e-government services at large scale. Government must take some initiatives to make the people aware about e-government services and also some efforts have to be done to eliminate the above mentioned challenges so that e-government services may accepted by the citizens successfully.

\section{REFERENCES}

[1] Adawi-AI, Yousafza, Z., \& Pallister, S. (September,2005). Concpetual Model of Citizen Adoption of E-government. Second International Coneference on Innovations in Information Technology (IIT'05), (pp. 1-10). Dubai, United Arab.

[2] Belanger, F. \&. (2008). Trust and Risk in E-Government Adoption. Journal of Strategic Information Systems, vol.17, no. 2 , 165-176.

[3] Belanger, F., \& Carter, L. (2005). Trust and Risk in EGovernment Adoption. Eleventh Americas Conference on Information Systems (pp. 1955-1964). NE, USA: Omaha.

[4] Bouma, G. (1996). The Research Process. Oxford: Oxford University, Press.

[5] Carter, L. \&. (2005). The Utilization of E-Government Services: Citizen, Trust, Innovation and Acceptance Factors. Information System Jouranl, vol 15, no.1 , 5-25.

[6] Davis, F. B. (1989). User Acceptance of Computer Technology: A Comparison of two Theoretical models. Management Science, vol.35, no.8, 982-1005.

[7] Dwivedi, S. K., \& Bharti, A. K. (n.d.). EGOVERNANCE IN INDIA - PROBLEMS AND ACCEPTABILITY. Jouranl of Theoretical and Applied Information Technology, 37-43.

[8] Economy of Punjab. (2013). Retrieved November 30, 2013, from http://www.mapsofindia.com/: http://www.mapsofindia.com/punjab/economy.html

[9] Geaographical Overview of Punjab. (2012). Retrieved Novemeber 30, 2013, from www.allaboutsikhs.com: http://www.allaboutsikhs.com/punjab/geographicaloverview-of-punjab

[10] Gilber, D. B. (2004). Barriers and Benefits in the Adoption of E-Government. International Journal of Public Sector Management, vol.17, no.4 , 286-301.

[11] GOVERNMENT OF PUNJAB ANNUAL PLAN 2013-14. (2013, April 30). Retrieved December 02, 2013, from http://planningcommission.gov.in/: 
[12] http://planningcommission.gov.in/plans/stateplan/Present ations13_14/punjab_2013_14.pdf

[13] Huang, Z. (2006). E-government Practices at Local Levels: An Analysis of U.S. Countries Websites. Issues in Information Systems, vol.VII no.2 , 165-170.

[14] Indian states ranking by literacy rate. (2011). Retrieved November 30, 2013, from http://en.wikipedia.org/: http://en.wikipedia.org/wiki/Indian_states_ranking_by_li teracy_rate

[15] Kumar, P., \& Bhanti, P. (September 2012). Prospects of E-Governance in India. International Journal of Engineering and Innovative Technology, volume 2, issue $3,335-339$.

[16] Kumar, V. m. (2007). Factors for Successful Egovernment Adoption: a Conceptual Framwork. Electronic Journal of e-government, vol.5, no.1 , 63-76.

[17] Leedy, P. (2005). Practical Research:Planning and Design, 6th edition. New Jersey: Prentice Hall.

[18] Mahajan, P. (2009). E-Governance initiatives in India with Special Reference to Punjab. Asia Pacific Journal of Social Sciences , 142-155.

[19] Malik, P., Priyanka, D., \& Verma, P. (July 2014). Challenges and Future Prospects for E-Governace in India. International Journal of Science, Engineering and Technology Research, volume 3, issue 7 , 1964-1972.

[20] McDaniel, C. \&. (1993). Contemperory Marketing Research, 2nd edition. St.Paul: West Publishing Company.

[21] Mittal, P., \& Kaur, A. (March 2013). E-Governance -A Challenge for India. International Journal of Advanced Research in Computer Engineering \& Technology , 1196-1199.

[22] Mittal, P., \& Kaur, A. (2013). E-Governance initiatives in the State of Punjab. International Journal of Research in Computer and Communication Technology, vol.2, issue 3 , 108- 111.
[23] Myser, M. (1997). Qualitative research in Information Systems. MIS Quarterly, vol.21 no.2 , 241-242.

[24] Palvia, S. C., \& Sharma, S. S. (2007). E-Government and E-Governance: Definitions/Domain Frmaework and Status around the world. Retrieved July 10, 2011, from www.iceg.net: http://www.iceg.net/2007/books/1/1_369.pdf

[25] Progressive Punjab. (2013). Retrieved November 30 2014, from www.progressivepunjab.gov.in: http://progressivepunjab.gov.in/content.aspx?id=2

[26] Punjab:An Overview. (n.d.). Retrieved Novemeber 30 2013, from www.oifc.in http://www.oifc.in/Uploads/MediaTypes/Documents/Pun jab-1207.pdf

[27] Reddick, C. (2005). Citizen Interaction with Egovernment: From the streets to servers. Government Information Quarterly, vol.22, no.1 , 38-57.

[28] Singh, V. \&. (n.d.). E-Governance in Punjab- A User Staisfaction Study. International Journal of Research in IT, Management and Engineering, vol. 2, issue 1 , 47-56.

[29] Singla, S. K., \& Aggarwal, H. (April 2012). Impact and Scope of e-Governance Initiatives in State of Punjab (INDIA). International Journal of Computer Applications, volume 44, No-14, 5-9.

[30] The Booming Economy of Punjab. (2013). Retrieved November 30, 2013, from http://www.thediplomaticsociety.co.za/: http://www.thediplomaticsociety.co.za/index.php/archive /archive/330-the-booming-economy-of-punjab

[31] Tung, L. \&. (2005). Adoption of Electronic Government Services Among Business Organizations in Singapore. Journal of Strategic Information Systems, vol.14, no.4, 417-440.

[32] Zikmund, M. (2000). Exploring Marketing Research, 7th edition. Forth Worth: Dryden Press. 